\title{
Effects of short-term exposure to heat stress on splanchnic metabolism in sheep
}

\author{
K. Taniguchi ${ }^{1}$, K. Nakamura, T. Yoneyama, T. Ito, \\ T. Sugino and T. Obitsu
}

Department of Animal Science, Graduate School of Biosphere Science, Hiroshima University, Higashihiroshima, 739-8528 Japan

\begin{abstract}
Four wethers with chronic indwelling catheters in the portal, hepatic and mesenteric veins as well as in the abdominal aorta were housed in temperature-controlled rooms at $20^{\circ} \mathrm{C}$ or $35^{\circ} \mathrm{C}$. The sheep consumed a diet at the level of maintenance requirements with both temperatures. Hepatic blood flow tended to be greater at $35^{\circ} \mathrm{C}$ than $20^{\circ} \mathrm{C}$. The absorption of acetate and propionate as well as the oxygen uptake by the portal-drained viscera were significantly greater at $35^{\circ} \mathrm{C}$ than at $20^{\circ} \mathrm{C}$. The increased oxygen uptake may be one cause of the heat load under hot temperature.
\end{abstract}

KEY WORDS: heat stress, nutrient absorption, oxygen consumption, splanchnic tissue, sheep

\section{INTRODUCTION}

Animal exposed to excessive heat load reduces feed intake to maintain homeothermy. Ambient temperature, relative humidity and metabolic heat with maintenance and production are important factors relating to the heat load. The portal-drained viscera (PDV) and liver use much oxygen due to the high metabolic activity, and the proportion of oxygen uptake by the total splanchnic (TS) tissues accounts for over $40 \%$ of total oxygen use by the whole body (Huntington, 1999). McGuire et al. (1989) have reported that the net flux of alpha amino nitrogen across the PDV of lactating cows was reduced by heat stress. However, few data on net flux of the other metabolites and oxygen consumption by PDV and liver under heat stress are available. We investigated the influence of hot temperature on metabolite net flux and oxygen consumption across the splanchnic tissues of sheep.

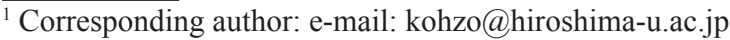




\section{MATERIAL AND METHODS}

Four wethers (average body weight $64.9 \mathrm{~kg}$ ) were surgically fitted with chronic indwelling catheters in the hepatic and hepatic portal vein, mesenteric vein and caudal aorta. All sheep housed in metabolic crates were offered the diet consisting of $70 \%$ alfalfa hay cubes and $30 \%$ rolled barley in 12 equal daily meals using automatic feeders. The daily amount of the diet was restricted at the maintenance energy level to exclude any influence associated with different feed intake. The room temperature as treatment was controlled at $20^{\circ} \mathrm{C}$ and $35^{\circ} \mathrm{C}$ with a relative humidity of 64 and $48 \%$, respectively. From the aspects of animal welfare, the confinement in $35^{\circ} \mathrm{C}$ room as heat stress treatment was restricted to three days. On day 3 , thus, blood samples of the artery and the portal and hepatic vein at $35^{\circ} \mathrm{C}$ were taken every $30 \mathrm{~min}$ for three hours. The blood samples at the comfortable room temperature $\left(20^{\circ} \mathrm{C}\right)$ were taken after 14 days for the preliminary period. $p$-Aminohippurate was continuously infused $(2 \% \mathrm{w} / \mathrm{v}, 1 \mathrm{ml} / \mathrm{min})$ into the mesenteric vein catheter for measuring blood flow. Treatment means were compared by paired-t test.

\section{RESULTS AND DISCUSSION}

There were no refusals of the offered diet with any of the temperature treatments. Table 1 summarizes the blood flow, oxygen consumption and metabolite net flux across the splanchnic tissues with both temperature treatments. Hepatic blood flow tended to be greater $(\mathrm{P}=0.15)$ at $35^{\circ} \mathrm{C}$ compared with $20^{\circ} \mathrm{C}$. Oxygen consumption by PDV at $35^{\circ} \mathrm{C}$ increased by $15 \%$ compared with $20^{\circ} \mathrm{C}$, which resulted in increased oxygen consumption by TS $(\mathrm{P}<0.05)$. Net absorption of acetate and propionate across PDV were greater $(\mathrm{P}<0.01)$ at $35^{\circ} \mathrm{C}$ than at $20^{\circ} \mathrm{C}$. The PDV net flux of isobutyrate and isovalerate also tended to be greater at $35^{\circ} \mathrm{C}(\mathrm{P}<0.14)$. Consequently, the absorption of total short chain fatty acids increased by $42 \%$ at $35^{\circ} \mathrm{C}$ compared with $20^{\circ} \mathrm{C}$. These results suggest that as heat stress promotes ruminal fermentation of ingested substrates, the increased short chain fatty acids as fermentation products need more oxygen for the absorption metabolism by the ruminal tissue. Heat stress reduces the gut motility of ruminants (Christopherson and Kennedy, 1983). In this study, reduced gut motility at $35^{\circ} \mathrm{C}$ might cause the prolongation of digesta retention time in the rumen, resulting in the increase absorption of fermentation products from same dietary substrates.

Although hepatic uptake of propionate at $35^{\circ} \mathrm{C}$ compared with $20^{\circ} \mathrm{C}$ increased $(\mathrm{P}<.05)$, the net glucose production by the liver did not differ. Because the liver can regulate gluconeogenesis under rigid glucose homeostasis, the increased propionate uptake at $35^{\circ} \mathrm{C}$ was used for other metabolic processes or fueled through the TCA cycle. Net release of propionate by TS was not different between the treatments. On 
the other hand, little uptake of acetate by the liver resulted in a tendency of the greater release by TS $(\mathrm{P}<0.15)$. Heat stress did not affect the net fluxes of butyrate and $\beta$ hydroxybutyrate across the splanchnic tissues.

Table 1. Blood flow, oxygen consumption and net flux of metabolites across portal, hepatic and total splanchnic tissues in sheep exposed to 20 and $35^{\circ} \mathrm{C}$

\begin{tabular}{|c|c|c|c|c|}
\hline Item & $20^{\circ} \mathrm{C}$ & $35^{\circ} \mathrm{C}$ & SE & $\mathrm{P}^{1}$ \\
\hline Portal blood flow, $\mathrm{L} / \mathrm{h}$ & 145 & 155 & 7.8 & 0.460 \\
\hline Hepatic blood flow, L/h & 169 & 184 & 9.6 & 0.150 \\
\hline \multicolumn{5}{|c|}{ Oxygen consumption, $\mathrm{mmol} / \mathrm{h}$} \\
\hline portal & 131 & 151 & 4.2 & 0.017 \\
\hline hepatic & 98 & 104 & 4.7 & 0.610 \\
\hline total splanchnic & 229 & 255 & 6.3 & 0.030 \\
\hline \multicolumn{5}{|l|}{ Net portal flux, $\mathrm{mmol} / \mathrm{h}$} \\
\hline acetate & 60.5 & 88.1 & 7.67 & 0.001 \\
\hline propionate & 18.3 & 25.1 & 1.73 & 0.006 \\
\hline isobutyrate & 0.8 & 1.3 & 0.16 & 0.138 \\
\hline butyrate & 3.7 & 3.3 & 0.61 & 0.553 \\
\hline$\beta$-hydroxybutyrate & 17.5 & 17.0 & 1.31 & 0.668 \\
\hline glucose & -4.6 & -6.5 & 4.09 & 0.821 \\
\hline NEFA & 2.6 & 3.4 & 1.30 & 0.759 \\
\hline \multicolumn{5}{|l|}{ Net hepatic flux, $\mathrm{mmol} / \mathrm{h}$} \\
\hline acetate & -0.6 & 43.2 & 18.3 & 0.310 \\
\hline propionate & -17.1 & -23.0 & 1.53 & 0.036 \\
\hline isobutyrate & -0.4 & -1.2 & 0.21 & 0.077 \\
\hline butyrate & -2.2 & -1.8 & 0.42 & 0.608 \\
\hline$\beta$-hydroxybutyrate & 13.3 & 15.7 & 1.92 & 0.641 \\
\hline glucose & 19.3 & 21.5 & 4.07 & 0.847 \\
\hline NEFA & -6.3 & -6.0 & 1.04 & 0.876 \\
\hline \multicolumn{5}{|c|}{ Net total splanchnic flux, mmol/h } \\
\hline acetate & 59.8 & 131.3 & 22.95 & 0.147 \\
\hline propionate & 1.2 & 2.2 & 0.40 & 0.230 \\
\hline isobutyrate & 0.4 & 0.1 & 0.14 & 0.400 \\
\hline butyrate & 1.5 & 1.4 & 0.26 & 0.910 \\
\hline$\beta$-hydroxybutyrate & 30.8 & 32.7 & 2.47 & 0.672 \\
\hline glucose & 14.7 & 15.0 & 2.76 & 0.970 \\
\hline NEFA & -3.7 & -2.6 & 0.89 & 0.451 \\
\hline
\end{tabular}

${ }^{1}$ probability that treatments differ 


\section{CONCLUSIONS}

Hot temperature compared with comfortable environment at a same level of feed intake increased short chain fatty acids absorption from the digestive tract and PDV oxygen consumption. The increased oxygen consumption by PDV could be one cause of heat load driven from metabolic process under heat stress.

\section{REFERENCES}

Huntington G.B., 1999. Nutrient metabolism by gastrointestinal tissues of herbivores. In: H.J.C. Jung, Fahey G.C. Jr. (Editors). Nutritional Ecology of Herbivores. Amer. Soc. Anim. Sci. IL, pp. 312-336

Christopherson R.L., Kennedy P.M., 1983. Effect of thermal environment on digestion in ruminants. Can. J. Anim. Sci. 63, 447-496.

McGuire M.A., Beede D.K., DeLorenzo M.A., Wilcox C.J., Huntington G.B., Reynolds C.K., Collier R.J., 1989. Effects of thermal stress and level of feed intake on portal plasma flow and net fluxes of metabolites in lactating Holstein cows. J. Anim. Sci. 67, 1050-1060. 